\title{
Cumulative effects of an invasive species and nutrient enrichment on rock pool communities
}

Vye, Siobhan; Dick, Jaimie T. A.; Emmerson, Mark C.; O'Connor, Nessa E.

\section{Marine Ecology Progress Series}

DOI:

$10.3354 /$ meps 12529

Published: 26/04/2018

Peer reviewed version

Cyswllt i'r cyhoeddiad / Link to publication

Dyfyniad o'r fersiwn a gyhoeddwyd / Citation for published version (APA):

Vye, S., Dick, J. T. A., Emmerson, M. C., \& O'Connor, N. E. (2018). Cumulative effects of an invasive species and nutrient enrichment on rock pool communities. Marine Ecology Progress Series, 594, 39-50. https://doi.org/10.3354/meps12529

\footnotetext{
Hawliau Cyffredinol / General rights

Copyright and moral rights for the publications made accessible in the public portal are retained by the authors and/or other copyright owners and it is a condition of accessing publications that users recognise and abide by the legal requirements associated with these rights.

- Users may download and print one copy of any publication from the public portal for the purpose of private study or research.

- You may not further distribute the material or use it for any profit-making activity or commercial gain

- You may freely distribute the URL identifying the publication in the public portal ?
}

Take down policy

If you believe that this document breaches copyright please contact us providing details, and we will remove access to the work immediately and investigate your claim. 
1 Title: Cumulative effects of an invasive species and nutrient enrichment on rock pool

2 communities

3 Running head: Cumulative effects of multiple stressors

4 Authors: Siobhan R. Vye ${ }^{1,2,3 *}$, Jaimie T.A. Dick ${ }^{1,2,4}$, Mark C. Emmerson ${ }^{1,2,4}$, Nessa E.

5 O’Connor ${ }^{1,2,4,5}$

$6 \quad{ }^{1}$ School of Biological Sciences, Medical Biology Centre, Queen’s University Belfast, 97

7 Lisburn Road, Belfast, BT9 7BL, UK.

$8 \quad{ }^{2}$ Queen's University Marine Laboratory, 12-13 The Strand, Portaferry, Co. Down, Northern 9 Ireland, BT22 1PF, UK.

$10{ }^{3}$ Present address: School of Ocean Sciences, Bangor University, Askew Street, Menai Bridge, 11 Isle of Anglesey, LL59 5AB, UK.

$12{ }^{4}$ Institute for Global Food Security, Queen's University Belfast, 18-30 Malone Road, Belfast, 13 BT9 5BN, UK.

$14{ }^{5}$ Present address: School of Natural Sciences, Trinity College Dublin, Dublin 2, Ireland.

$15 *$ *orresponding author: Siobhan R. Vye, Email: s.vye@bangor.ac.uk 


\section{Abstract}

17 Most ecosystems are affected by multiple anthropogenic stressors simultaneously, however, there is a lack of information describing the cumulative effects of many common stressor pairs. Consequently, we have but a rudimentary understanding of the roles that stressor characteristics and environmental context play in determining interactions among stressors. Nutrient enrichment often affects coastal ecosystems that may have already been affected by invasive species. To identify the effects of nutrient enrichment on communities under different invasion scenarios, the presence of the invasive fucoid algae, Sargassum muticum, and nutrient conditions were manipulated in the field to test for their independent and cumulative effects. Their combined effects on the diversity and functioning of rock pool communities were quantified. Rock pools with S. muticum contained fewer species, lower macroalgal and microalgal biomass, and their overall benthic assemblage structure differed from pools without $S$. muticum. Both the presence of $S$. muticum and nutrient enrichment affected different functional groups of algae differently.

30 Their cumulative effects, however, did not differ with increasing intensity of nutrient enrichment. Furthermore, invaded communities from which $S$. muticum had been removed manually, tended towards greater species richness following removal than pools where $S$. muticum remained present, indicating a potential for recovery. These findings highlight the importance of identifying the cumulative effects of multiple stressors on the responses of individual functional groups, alongside effects on overall assemblage structure, in order to fully understand the consequences for ecosystems.

38 Keywords: Sargassum muticum, eutrophication, community ecology, biodiversity, multiple stressors, coastal ecology 


\section{Introduction}

41 An emerging field of research aims to disentangle the impacts of multiple anthropogenic stressors and to better predict their cumulative effects on ecosystems (Crain et al. 2008,

43 Darling \& Côté 2008, Russell \& Connell 2012, Boyd \& Hutchins 2012). Among the most common anthropogenic stressors in marine ecosystems are invasive species (Crain et al. 2008). Invasive species often occur in coastal and estuarine environments that are already affected by one or more anthropogenic stressors, which may affect invasion success and impact (Vitousek et al. 1997, Lotze et al. 2006). Predicting the impacts of invasive species under multiple stressor scenarios is limited by our lack of understanding of how environmental or experimental context determines their effects in natural communities and similarly, how invasive species alter the impacts of other stressors. The introduction of a secondary stressor, such as nutrient enrichment, to a system that is already under stress from an invasive species, may lead to stress-induced tolerance or stress-induced sensitivity of the community (Vinebrooke et al. 2004). Stress-induced sensitivity may occur when the effects of a stressor leads to a community that is less resilient towards the second stressor and the cumulative impact of the stressors is synergistic or greater than the sum of the individual effects. Alternatively, stress-induced tolerance may occur when the effects of the initial stressor drives the community to be more resilient to the effects of the second stressor and thus, the second stressor has a reduced impact and the cumulative impact of the two stressors is antagonistic (Folt et al. 1999, Vinebrooke et al. 2004). Where the combined effects of multiple stressors do not interact, their cumulative effect is additive, or equal to the sum of

61 the individual effects (e.g. Vye et al. 2017).

62 Coastal ecosystems that are influenced by invasive species are often exposed to both press

63 and pulse nutrient enrichment from a range of sources, such as land run-off and sewage

64 outfalls (Lotze \& Worm 2002, Lapointe et al. 2004). Nutrient enrichment may influence the 
invasion process in some invasive seaweeds (Sanchez \& Fernandez 2006, Vaz-Pinto et al.

66

67 2013, Uyà et al. 2017, Vieira et al. 2017). For example, nutrient enrichment has been shown to increase the invasion success of Sargassum muticum, a common invasive macroalga in Europe (Vieira et al. 2017), suggesting not only could nutrient enrichment affect the native community independently, but it could also increase the impacts of the invader on the native community structure and functioning. Therefore, the cumulative effect of these stressors would be synergistic. Alternatively, S. muticum could reduce the impacts of nutrient enrichment itself on the native community by exploiting the excess resource in nutrient enriched ecosystems, as outlined in the fluctuating resources theory presented by Davis et al. (2000). In this scenario, there may be effects of increased invasion success of the invader on the community, however, the interactive effect may be antagonistic as the effect of nutrient enrichment on community structure and functioning would be lessened.

The majority of experimental studies to date have focused primarily on the introduction of both nutrient enrichment and invasive species simultaneously (Vye et al. 2015, Vieira et al. 2017). Nutrient enrichment events, however, often occur in systems where invasive species are already established (Lotze et al. 2006). Testing how an established invasive species alters the impacts of a nutrient enrichment event on the native community is important to enable us to understand the cumulative effects of the stressors in a realistic scenario (Strayer 2012). Furthermore, a common management approach to invasive species is to undertake manual removal of individuals either for eradication or population control (Thresher \& Kuris 2004). If the invasive species is modulating the impacts of another stressor, such as nutrient enrichment, indirect effects of removing the invader from the system can be complicated and unpredictable. As such, there is a need for experimental studies that allow a better understanding of the future consequences of invasive species management in coastal ecosystems influenced by multiple stressors (Zavaleta et al. 2001). 
90 In addition to the presence or absence of stressors, other stressor characteristics, such as intensity or temporal variability, may also have a role in determining the cumulative effects of multiple stressors (Benedetti-Cecchi et al. 2006, Molinos \& Donohue 2010, O'Connor et al. 2015). Stressor intensity has been shown previously to determine the cumulative impacts

94 of invasive species and other stressors (Vye et al. 2015). Specifically, a recent study identified an antagonistic cumulative effect of the presence of the invasive fucoid, $S$. muticum, and nutrient enrichment on total algal biomass accumulation in an assembled rock pool community, but only at certain levels of nutrient enrichment (Vye et al. 2015). Such shifts in algal biomass production are an important proxy for energy flow and although not analogous with primary productivity per se, are indicative of an implicit change in ecosystem

100 functioning (O’Connor \& Crowe 2005, Masterson et al. 2008).

101 The aim of this study, therefore, was to identify and characterise the effects of nutrient

102 enrichment on communities in rock pools that have been invaded by $S$. muticum and compare

103 them with rock pool communities that have not been invaded by S. muticum. We also removed S. muticum manually from pools and compared these communities to those with and without S. muticum. This removal treatment was an essential control for the potentially confounding influences of factors that may covary with the presence of $S$. muticum. It also

107 allowed us to assess the potential impacts of invader management by means of targeted 108 removal over the peak growth season. The hypotheses tested were that: 1) the presence of an invasive species will modulate the effects of nutrient enrichment on benthic assemblage structure and diversity; 2) the presence of invasive species and nutrient enrichment will have

111 different cumulative effects on different algal functional group biomass; and 3) the level, or

112 intensity, of nutrient enrichment will determine the cumulative impacts of the presence of an

113 invader and nutrient enrichment on benthic assemblage structure, diversity and functional 114 group biomass. 


\section{Materials and methods}

\section{Experimental site}

117 The experiment was conducted in intertidal rock pools on an exposed rocky shore at

118 Muighinis, Co. Galway, Ireland (53¹7'39.46"N, 951'2.87"W) between April and June 2014.

119 The shore is comprised of exposed granite bedrock and has a tidal range of approximately

120 four metres (Firth \& Crowe 2010). These rock pool assemblages were comprised of many

121 different morphological forms of algae including fucoids, such as Fucus serratus and

122 Halidrys siliquosa, ephemeral green algae, including Ulva spp. and Cladophora rupestris and

123 many species of red algae, both encrusting (e.g. Lithothamnium sp. and Mesophyllum

124 lichenoides) and branched (e.g. Gelidium spp. and Polysiphonia spp.). Invertebrate

125 communities in the pools included gastropod grazers, such as the limpet, Patella

126 ulyssiponensis, the topshell, Gibbula umbilicalis and the periwinkle, Littorina littorea

127 (O’Connor \& Crowe 2005). Within the past two decades, a large proportion of the rock pools

128 have also been colonised by the invasive fucoid Sargassum muticum (Baer \& Stengel 2010),

129 which increases in percentage cover during summer (February to July locally; Baer \& Stengel

130 2010).

131 Experimental design

132 A field experiment was designed to test for the individual and cumulative effects of the

133 presence of an invasive species and nutrient enrichment on rock pool assemblage structure

134 and functioning. Based on an orthogonal experimental design, the experiment allowed

135 mensurative (i.e. natural presence vs. natural absence of invader) and manipulated

136 comparisons (i.e. natural presence vs. manipulated removal of invader, Hurlbert 1984). The

137 factorial experiment had two fixed factors: presence of an invader (three levels: present,

138 absent and removed) and nutrient enrichment (three levels: ambient, intermediate, high), and 
139 tested for all interactions among treatments. All nine treatments were replicated five times,

140 each in separate rock pools with a minimum distance of two metres apart, yielding 45

141 experimental units. Fifteen rock pools without Sargassum muticum and thirty rock pools with

142 S. muticum present were selected randomly on the mid shore. Sargassum muticum was

143 removed carefully (using a flat chisel to ensure the whole of the holdfast was removed,

144 preventing plant regrowth) from half of the rock pools with $S$. muticum present (15 pools).

145 This removal treatment was important to test for and assess any potentially confounding

146 variables that may have co-varied with the presence of S. muticum (O'Connor et al. 2006,

147 Underwood 2009) and to identify nutrient enrichment effects on recovering communities

148 after invader removal. All rock pools were similar in size (mean \pm S.E.: length $=118.6 \pm 4.5$

$149 \mathrm{~cm}$; width $=66.4 \pm 3.1 \mathrm{~cm}$; and depth $=14.4 \pm 0.8 \mathrm{~cm})$, within the same shore height and

150 exposure. The initial percentage cover of $S$. muticum in all invaded pools was $7.3 \pm 1.7 \%$

151 (mean \pm S.E.), increasing to $18.9 \pm 6.4 \%$ cover by the end of the experiment (peak growth

152 period).

153 Rock pools were assigned randomly to treatments $(n=5)$. To manipulate nutrient

154 concentrations in nutrient enriched pools, Everris Osmocote ${ }^{\circledR}$ Exact (Geldermalsen,

155 Netherlands) slow release fertiliser pellets (11N: 11P: 18K) were used (Worm et al. 2000,

156 Atalah \& Crowe 2010, O'Connor et al. 2015). Fertiliser was contained within mesh cases

157 attached to the base of each pool. Ambient treatments contained an empty mesh bag to

158 control for potential artefact effects of the presence of the bag. Intermediate and high nutrient

159 enrichment treatments contained $1 \mathrm{~g} \mathrm{l}^{-1}$ and $3 \mathrm{~g} \mathrm{l}^{-1}$ of fertiliser pellets respectively. At the end

160 of the experimental period, water samples were taken immediately after the emersion of the

161 pools at low tide and were analysed using an autoanalyzer for dissolved inorganic nitrogen

162 (DIN) and phosphate to confirm the efficacy of the nutrient enrichment treatments. Ambient

163 treatments contained $1.00 \pm 0.12 \mu \mathrm{m} \mathrm{l}^{-1} \mathrm{DIN}$ and $0.17 \pm 0.01 \mu \mathrm{m} \mathrm{l}^{-1}$ phosphate. Intermediate 
164 nutrient enrichment treatments contained $19.22 \pm 3.67 \mu \mathrm{m} \mathrm{l}^{-1}$ DIN and $3.11 \pm 0.62 \mu \mathrm{m} \mathrm{l}^{-1}$

165 phosphate, and high nutrient enrichment treatments contained $29.99 \pm 5.64 \mu \mathrm{m} \mathrm{l}^{-1} \mathrm{DIN}$ and

$1664.25 \pm 1.01 \mu \mathrm{m} \mathrm{l}^{-1}$ phosphate $\left(\mathrm{DIN}: \mathrm{MS}=38.12, F_{2,40}=20.15, P<0.05\right.$, SNK post-hoc: $\mathrm{A}<$

$167 \mathrm{~N}+<\mathrm{N}++$; phosphate: $\mathrm{MS}=6.64, F_{2,40}=7.60, P<0.05$, SNK post-hoc: $\left.\mathrm{A}<\mathrm{N}+<\mathrm{N}++\right)$. As

168 the nutrient treatment represented a pulse of nutrient enrichment similar to that of land based

169 run-off into the intertidal zone (Sharp 1983, O’Connor et al. 2015), a further subset of

170 samples were taken 5 hours after initial emersion to identify how much nutrient flux occurred

171 in the pools during the emersion period. In intermediate nutrient enrichment treatments, DIN

$172\left(40.09 \pm 12.76 \mu \mathrm{m} \mathrm{l}^{-1}\right)$ approximately doubled and phosphate concentrations $(35.58 \pm 11.23$

$173 \mu \mathrm{m} \mathrm{l}^{-1}$ ) increased by a magnitude of ten over five hours. In high nutrient enrichment

174 treatments DIN $\left(111.66 \pm 57.74 \mu \mathrm{m} \mathrm{l}^{-1}\right)$ approximately quadrupled and phosphate

175 concentrations $\left(78.24 \pm 28.27 \mu \mathrm{m} \mathrm{l}^{-1}\right)$ increased by a magnitude of twenty. These

176 concentrations are unlikely to limit macroalgal growth (Gordillo et al. 2002) and are similar

177 to levels achieved in previous nutrient enrichment studies in intertidal systems (Atalah \&

178 Crowe 2010, O’Connor et al. 2015).

179 The experiment ran between April and June 2014 to focus on the peak growth period of the

180 invasive species, S. muticum (Baer \& Stengel 2010), which tends to die back in the winter

181 months. This duration also reflects the length of similar multiple stressor experiments in

182 artificial systems to allow for broad comparisons of findings (Boyer et al. 2009, Vye et al.

183 2015).

184 Response variables

185 Benthic assemblage structure (percentage cover of macroalgae and abundance of slow

186 moving or sessile invertebrates $>1 \mathrm{~cm}$ ) was quantified using a $25 \mathrm{~cm}$ x $25 \mathrm{~cm}$ quadrat with 64

187 intersections prior to the application of nutrient enrichment treatments and before S. muticum 
was removed from the removal treatments, to test for any initial differences between invaded and non-invaded communities. One quadrat for each pool may have reduced statistical power, however, we have based our analyses on means of each pool (replicate) for each treatment. This size was chosen as it allowed a standard random sample to be taken in all pool shapes

192 including the narrowest pools in the range. Quantification of benthic assemblage structure 193 was repeated at the end of the experiment, similarly using a randomly placed $25 \mathrm{~cm}$ x $25 \mathrm{~cm}$ quadrat with 64 intersections in each rock pool. All species present in the quadrat, but not beneath an intersection, were recorded as $0.5 \%$ cover. Algal taxa were identified to the lowest practicable taxonomic level using taxonomic keys (e.g. Dixon \& Irwine 1977, Hiscock

197 1986) and epiphytes, which are common in this system, were not distinguished from other

198 epilithic algae for analyses. Abundance of slow moving and sessile invertebrates $(>1 \mathrm{~cm})$ was

199 also estimated at the same time. There were no initial differences in benthic assemblage structure between pools assigned to each treatment, including invaded and non-invaded communities (PERMANOVA: $\mathrm{MS}=0.1869$, pseudo- $F_{2,36}=1.383, P>0.05$ ) based on an extensive survey prior to treatment allocation at the start of the experiment and before the anticipated S. muticum seasonal growth period.

At the conclusion of the experiment, species richness (N), Shannon-Wiener diversity $\left(H^{\prime}\right)$ and Pielou's evenness $(J)$ indices were also estimated for each pool based on percentage cover and abundance data. Furthermore, all benthic taxa were classified into functional groups and analysed to test for more general trends based on potential functional traits (Jänes et al. 2017, Table S1 in Supplementary Material). Algal taxa were assigned to functional groups based on their expected response to treatments and functional role in the rock pool community (Arenas et al. 2006). These included turf-forming algae (taxa typically $<5 \mathrm{~cm}$ vertical height) and

211 sub-canopy space-holding algae, which were hypothesised to be affected by shading by $S$. 
213 be affected by competition for resources, such as space, by S. muticum (Viejo 1997). Green

214 ephemerals and coralline algae were also classified into different functional groups (distinct

215 from turf-forming taxa) because these groups have been shown to have different responses to

216 nutrient enrichment (Hawkins et al. 1994, Delgado \& Lapointe 1994, Karez et al. 2004,

217 O’Connor 2013, Vieira et al. 2017). Invertebrate functional groups included grazing

218 gastropods (e.g. winkles, Littorina littorea), suspension feeders (e.g. beadlet anemone, Actina

219 equina) and mobile predators (e.g. dog whelk, Nucella lapillus; Little et al. 2009).

220 At the end of the experiment, destructive samples of algae were taken to quantify the effects of the presence of $S$. muticum and nutrient enrichment on total algal biomass and the biomass of each algal functional group (canopy, sub-canopy, turf, coralline, and green ephemerals, Table S1 in Supplementary Material). Algae were collected from within each quadrat, sorted into taxa, except for encrusting coralline algae (e.g. Lithothamnium sp.) and dried to a constant mass (at $60^{\circ} \mathrm{C}$ ). Up to $80 \%$ of coralline algae consists of calcium carbonate and thus dry biomass of coralline algae was adjusted by a conversion factor of 0.2 (Griffin et al. 2010, Mrowicki \& O’Connor 2015). Microalgal biomass was also estimated in situ by quantification of chlorophyll $a$ concentration of biofilm in the rock pools (Murphy et al. 2005, Carpentier et al. 2013, Kahlert \& McKie 2014, Mrowicki et al. 2014). Three measurements $\left(1 \mathrm{~cm}^{2}\right.$ each) were taken randomly from the base of the pools using a benthic

231 fluorometer (BenthoTorch, bbe Moldaenke ${ }^{\circledR}$ ). The mean of these measurements was used in analyses to incorporate potential effects of small-scale variability (Sandulli \& Pinckney 1999, Murphy et al. 2005). Three pools that had S. muticum removed and one pool from the

234 treatment where it was thought $S$. mutium was absent were excluded from the analysis

235 because the presence of the invader was noted ( $>0.5 \%$ cover $)$ at the end of the experiment, suggesting the experimental treatment was not effective in these pools. 
237 Permutational multivariate analysis of variance (PERMANOVA; Anderson 2001, McArdle \&

238 Anderson 2001) was used to test hypotheses relating to benthic assemblage structure

239 (percentage cover of macroalgae and abundance of slow moving or sessile invertebrates

$240>1 \mathrm{~cm}$ ) at the end of the study, with a similar factorial experimental design (two fixed factors:

241 the presence of S. muticum [three levels]; and nutrient concentration [three levels]). Non-

242 metric multi-dimensional scaling (nMDS) was used to visualise differences among

243 assemblages based on dissimilarities of their assemblage structure. Similarities of percentages

244 (SIMPER) analyses were used to identify which taxa contributed most to differences in

245 assemblage structure among treatments (Clarke \& Warwick 2001). All multivariate analyses

246 were conducted on Bray-Curtis dissimilarity matrices with 9,999 permutations of residuals

247 under the reduced model and tested for all possible interactions among treatments. Data were

248 square-root transformed to reduce the influence of the highly abundant canopy species

249 (Clarke \& Warwick 2001). The percentage cover estimates of S. muticum were not included

250 in analyses of assemblage structures to prevent confounding independent (manipulated) and

251 dependent (response) variables (Huston 1997) and to identify the impact of S. muticum on the

252 rest of the assemblage (Thomsen et al. 2016). Post-hoc pairwise $t$-tests were used to identify

253 differences between levels of significant terms. Post-hoc PERMDISP routines were

254 conducted on significant terms, after inspection of the nMDS plots, to detect differences in

255 the assemblages caused by treatment effects on the variation in assemblage structure rather

256 than shifts in assemblage structure. Percentage cover and abundance of taxa were classified

257 into functional groups and reanalysed to test for effects of the presence of S. muticum and

258 nutrient enrichment on functional diversity (Table S1 in Supplementary Material).

259 Analysis of variance (ANOVA) was used to test hypotheses relating to species richness,

260 Shannon-Wiener diversity and Pielou's evenness using a similar design with two fixed

261 factors: S. muticum (three levels) and nutrient concentration (three levels). Sargassum 
muticum was not included in this analysis in order to identify effects on native diversity. In addition to the multivariate tests on functional group abundance data, a univariate approach was also undertaken to identify the biomass response of individual algal functional groups to S. muticum and nutrient concentration. This approach was considered prudent because algal biomass may be more indicative of different algal functional group contributions to energy flow and productivity than percent cover estimates (Masterson et al. 2008, Atalah \& Crowe 2010, Crowe et al. 2011, White \& Shurin 2011). To further disentangle the effect of the invader, biomass results for total macroalgae and canopy algae were analysed with and without S. muticum biomass (Thomsen et al. 2016). Data were first tested for normality and homogeneity of variances using Shapiro-Wilk and Levene's tests and were transformed where assumptions were not met. Shannon-Wiener diversity, green ephemeral, turf, coralline and canopy algal biomass were square-root transformed, microalgal biomass data were natural-log transformed and Pielou's evenness data were arcsine transformed. StudentNewman-Keuls post-hoc procedures were used to make comparisons among levels of significant terms. Post-hoc test results presented are with S. muticum biomass included. All analyses were undertaken in R 3.1.0 (R Development Core Team 2011) and PRIMER v6

278 (Clarke \& Gorley 2006, Anderson et al. 2008).

\section{Results}

At the end of the experiment, there was an effect of the presence of S. muticum on benthic assemblage structure (MS $=4056.5$, pseudo- $\left.F_{2,32}=2.397, P=0.006\right)$, however, there was no effect of nutrient enrichment $\left(\mathrm{MS}=771.9\right.$, pseudo- $\left.F_{2,32}=0.456, P>0.05\right)$. Post-hoc tests showed that assemblage structure in rock pools without $S$. muticum differed from those where it was present (Absent $\neq$ Present, $t=1.793, P=0.008$, Fig. 1 ) and from pools where it was removed experimentally (Absent $\neq$ Removed, $t=1.731, P=0.004$, Fig. 1 ). When all taxa were classified into functional groups, there remained an effect of the presence of S. muticum 
287 on benthic assemblage structure (MS $=1748.4$, pseudo- $\left.F_{2,32}=2.320, P=0.042\right)$ and no

288 effect of nutrient enrichment (MS $=275.61$, pseudo- $\left.F_{2,32}=0.366, P>0.05\right)$. Post-hoc tests

289 again identified differences in assemblages without $S$. muticum compared to rock pools where

290 S. muticum was present (Absent $\neq$ Present, $t=1.689, P=0.046$ ) or had been removed

291 (Absent $\neq$ Removed, $t=2.240, P=0.007$ ). SIMPER analyses showed that these differences

292 in benthic assemblage structure were driven primarily by algal taxa, which were dominant in

293 both richness and abundance, rather than faunal taxa, and therefore, algal taxa were focused

294 on for the rest of the analysis. There was a greater proportion of the canopy alga, Fucus

295 serratus, the turf and sub-canopy algae (Ceramium spp. and Chondrus crispus), and all

296 ephemeral green algae (Chaetomorpha sp., Ulva spp. and Cladophora rupestris) in

297 treatments without $S$. muticum compared to treatments where it was present or had been

298 removed (Table S2 in Supplementary Material). In addition, there was an effect of the

299 presence of $S$. muticum on variation in benthic assemblage structure (PERMDISP: $F_{2,38}=$

$3004.886, P=0.016$, Fig. 1), however, post-hoc tests could not identify conclusively where

301 differences among treatments lay because pools with and without $S$. muticum had similar

302 variation in assemblage structure to rock pools where S. muticum had been removed

303 experimentally. There was also an effect of the presence of $S$. muticum on species richness

$304\left(\mathrm{MS}=34.15, F_{2,32}=3.4165, P=0.045\right.$, Fig. 2$)$, however, post-hoc tests could not identify

305 where differences lay because although species richness differed, i.e. was lower when $S$.

306 muticum was present than when it was absent, both these treatments were similar to the rock

307 pools where $S$. muticum was removed experimentally (Fig. 2). Nutrient enrichment did not

308 affect species richness $\left(\mathrm{MS}=8.45, F_{2,32}=0.848, P>0.05\right)$. Also, there was no effect of the

309 presence of $S$. muticum $\left(\mathrm{MS}=0.052, F_{2,32}=2.267, P>0.05\right)$, nor nutrient enrichment (MS

$\left.310=0.006, F_{2,32}=0.264, P>0.05\right)$ on Shannon-Wiener diversity, nor were there any effects of 
311 the presence of $S$. muticum (MS $\left.=0.001, F_{2,32}=0.447, P>0.05\right)$ or nutrient enrichment (MS

$\left.312=0.001, F_{2,32}=0.341, P>0.05\right)$ on Pielou's evenness.

313 There was an effect of the presence of S. muticum on total macroalgal biomass (Table 1a, Fig.

$3143 \mathrm{~A}$ ), however post-hoc tests were not fully conclusive because, although algal biomass was

315 greater in the pools where S. muticum was present compared to pools where it was absent,

316 both these treatments were similar to the treatment from which S. muticum was removed

317 experimentally. There was no effect of nutrient enrichment on total macroalgal biomass

318 (Table 1a, Fig. 3A). In terms of responses of individual functional groups of algae, pools

319 where $S$. muticum was absent had a greater biomass of canopy algae than pools with $S$.

320 muticum and pools where $S$. muticum had been removed, but there was no effect of nutrient

321 enrichment (Table 1b, Fig. 3B). Furthermore, the impacts of S. muticum on total and canopy

322 algal biomass did not differ depending on whether $S$. muticum biomass was included in the

323 analysis or not (Table 1a \& b, Fig. 3A \& B). The effect of the presence of S. muticum on the

324 biomass of sub-canopy algal species differed with nutrient enrichment (as indicated by the

325 significant interaction between presence of $S$. muticum and nutrient enrichment, Table 1c),

326 however, post-hoc tests were unable to identify where differences among treatments lay (Fig.

327 3C). The effects of the presence of S. muticum on the biomass of green ephemeral algae also

328 differed with nutrient enrichment, however, post-hoc tests could not determine where

329 precisely differences among treatments lay (Table 1f, Fig. 3F). There was no effect of the

330 presence of $S$. muticum or nutrient enrichment on coralline or turf algal biomass (Table 1d \&

331 e, Fig. 3D \& E). Microalgal biomass was lower in rock pools where S. muticum was present

332 or removed compared to pools without S. muticum (Table 1g, Fig. 3G) and there was no

333 effect of nutrient enrichment on microalgal chlorophyll $a$ concentration (Table 1g, Fig. 3G).

\section{Discussion}


335 This study found that pools where Sargassum muticum was present had different benthic

336 assemblage structure from those without $S$. muticum, where the former tended to have a lower

337 abundance of canopy algae and reduced benthic species richness. Surprisingly, none of the

338 effects on assemblage structure were modulated by nutrient enrichment. Our findings did

339 show, however, that nutrient enrichment had variable interactive cumulative effects with the

340 presence of $S$. muticum on the biomass of some algal functional groups. There was no clear

341 effect of intensity of nutrient enrichment, which suggests that, contrary to our hypotheses, the

342 intensity of this stressor was not important in determining the cumulative effects in this rock

343 pool system.

344 The invasion-driven shift in benthic assemblage structure coincided with the peak algal

345 growth period. Unlike many native algal species, $S$. muticum undergoes senescence during

346 the winter months, where it loses a large proportion of biomass and percentage cover, re-

347 growing during spring and reaching peak biomass during summer months (Wernberg et al.

348 2000, Baer \& Stengel 2010). When taxa were classified into functional groups and re-

349 analysed, the overall assemblage structure still differed where $S$. muticum was present, which

350 shows that the effect of S. muticum was apparent on whole functional groups of algae not

351 based on individual species responses. The increase in percentage cover of S. muticum during

352 the experiment may have reduced light penetration to the understory species (Britton-

353 Simmons 2004), and reduced space available for other canopy species, such as $F$. serratus

354 (Viejo 1997, White \& Shurin 2011). Furthermore, increased light intensity, daylight duration

355 and temperature during the summer stimulates the growth of many native sub-canopy algal

356 species, such as Chondrus crispus and Furcellaria lumbricalis (Bird et al. 1979), which may

357 increase competition for primary resources with S. muticum (Britton-Simmons 2004). Thus,

358 seasonal macroalgal growth, in combination with increases in percentage cover of $S$. 
muticum, may have led to seasonal differences in benthic assemblages between the invaded and non-invaded communities (Thomsen et al. 2005).

361 The differences among benthic assemblages were characterised by a tendency towards increased variability of assemblage structure and towards decreased species richness in the presence of S. muticum. High spatial variability has been suggested to be a symptom of stressed communities when exposed to anthropogenic disturbances (Warwick \& Clarke 1993, Cottingham et al. 2001, Ives \& Carpenter 2007, Donohue et al. 2013). Although the findings of this study are contrary to others that identified an invasive species-driven homogenisation of communities (Olden \& Rooney 2006, Baiser et al. 2012), increased variability may be expected owing to the non-linearity and context-dependency of invasion impacts (Parker et al. 1999, Thomsen et al. 2011, Vaz-Pinto et al. 2014). Our invaded assemblages also tended to be less species rich, which may contribute to increased variability within invaded rock pools (Loreau et al. 2001, Campbell et al. 2011). Increases in community variability driven by invasion could decrease the predictability of the response of communities to biological invasions. This could lead to 'ecological surprises' becoming more common and complicating management decisions (Paine et al. 1998).

Benthic assemblage structure was less variable and tended towards greater species richness and total algal biomass in assemblages where $S$. muticum had been removed, compared to assemblages where $S$. muticum remained present. Although some of these responses were not conclusive, this does indicate some potential for recovery. This finding provides some initial evidence that the removal or management of $S$. muticum could allow intertidal communities to begin to recover within a relatively short time period. However, there was no evidence of the recovery of canopy algal biomass, which may be owing to the slow growth rates associated with the primary native canopy species, Fucus serratus (Knight \& Parke 1950).

383 The temporal duration of this study, designed to look at impacts during the main growth 
season of S. muticum, may not have been long enough for these slow growing species to show detectable signs of recovery. Other invasive macroalgal removal studies have found a lag of five or more months before some species or functional groups of algae recover from the impacts of an invasive macroalgae, which can depend on other perturbations in the system as well as the original biomass of the invader (Piazzi \& Ceccherelli 2006, Gribben et al. 2013). Although this study occurred over the main period of $S$. muticum growth, and therefore the main period of expected impact, further work should follow the trajectory of macroalgal communities over a longer duration to assess the full potential for community recovery after $S$. muticum removal.

Previous studies have identified antagonistic cumulative effects of the presence of S. muticum and nutrient enrichment on total algal biomass in artificial assemblages (Vye et al. 2015). The current study however, showed that the effects of S. muticum on total macroalgal and microalgal biomass were not determined by nutrient enrichment. Here, the presence of $S$. muticum was characterised by less total algal biomass regardless of whether S. muticum was included in the analysis, indicating that the presence of $S$. muticum drove decreases in the biomass of native species, such as the native canopy alga, F. serratus. Furthermore, there was also less total microalgal biomass in treatments where $S$. muticum had been removed suggesting that effects on total microalgal biomass were persistent even after removal of the invasive species. This could be due to a number of mechanisms, for example, the increase in algal biomass could indicate increased competition for resources with microalgae, such as light and space, inhibiting recovery (Williams et al. 2000). Natural communities, such as the rock pools in this study, are more complex and provide greater potential for species

406 interactions than the artificially assembled communities used in mesocosm experiments

407 (Bracken et al. 2008, Stachowicz et al. 2008, Crowe et al. 2012, Vye et al. 2015). Such species interactions may moderate the cumulative impacts of stressors and reduce the 
sensitivity of communities to changes in stressor characteristics, such as intensity (Petersen \&

410 Hastings 2001). Furthermore, our previous mesocosm-based study, introduced both stressors

411 simultaneously (Vye et al. 2015), whereas this field study introduced nutrient enrichment to

412 pools where $S$. muticum was already established. The introduction of a second stressor to an

413 already stressed or destabilised system may determine the interactive effect of the stressors

414 (Mrowicki et al. 2016, Donohue et al. 2016). Our findings highlight the importance of testing

415 multiple stressor hypotheses in different of environmental contexts, i.e. field as well as

416 mesocosm experiments, in order to better understand the cumulative impacts of different

417 communities and assemblages. This study has an obvious limitation in that it was only

418 conducted on a single shore. Replicating multiple stressor studies at multiple sites would

419 incorporate spatial variation in environment context which could then be tested explicitly

420 (Bustamante \& Branch 1996, Mrowicki et al. 2014).

421 Functional diversity has been shown previously to be an important determinant of the invasibility of a community (Britton-Simmons 2006, Arenas et al. 2006). Our findings suggest that species that use primary resources, such as light and space, differently may also respond differently to the cumulative effects of invasion and nutrient enrichment. The cumulative effects identified in this study were not consistent across all algal functional groups present, because nutrient enrichment affected invasion effects on green and subcanopy algae, but not on canopy algae or turf algae. Mechanisms behind this interactive effect are unclear, however, it is possible that $S$. muticum may have limited light penetration to other algae (Britton-Simmons 2004), possibly offsetting nutrient enrichment effects on

430 growth. Differences in the cumulative effects among functional groups may lead to further 431 consequences for communities, including decreased resistance and resilience to other 432 invasive species and anthropogenic stressors (Elmqvist et al. 2003, Folke et al. 2004). To conclude, this study shows complex cumulative effects of nutrient enrichment on 
434 communities under different invasion scenarios, including the removal of the invader from

435 the system. These findings highlight the importance of identifying the cumulative effects of

436 multiple stressors on the responses of individual functional groups, alongside effects on

437 overall assemblage structure, in order to fully understand the consequences for ecosystems.

\section{Acknowledgements}

439 We thank Brian Stewart of the Agri-Food and Biosciences Institute for nutrient analysis,

440 Nadescha Zweschke, Alice Goward Brown and Katherine Oliver for assistance with the

441 experiment, and the staff of Carna research station, NUIG, for provision of facilities. We also

442 thank four anonymous reviewers whose comments greatly improved this manuscript. This

443 study was completed as part of a $\mathrm{PhD}$ funded by the Department for Employment and

444 Learning Northern Ireland with additional funding from the Challenger Society for Marine

445 Science and a Royal Society Research Grant (RG 120432). 


\section{Literature cited}

447 Anderson MJ (2001) Permutation tests for univariate or multivariate analysis of variance and 448 regression. Can J Fish Aquat Sci 639:626-639

449 Anderson MJ, Gorley RN, Clarke KR (2008) PERMANOVA+ for PRIMER: Guide to 450 Software and Statistical Methods. PRIMER-E Ltd, Plymouth, UK

451 Arenas F, Sánchez I, Hawkins SJ, Jenkins SR (2006) The invasibility of marine algal 452 assemblages: role of functional diversity and identity. Ecology 87:2851-61

453 Atalah J, Crowe TP (2010) Combined effects of nutrient enrichment, sedimentation and grazer 454 loss on rock pool assemblages. J Exp Mar Bio Ecol 388:51-57

Baer J, Stengel DB (2010) Variability in growth, development and reproduction of the non456 native seaweed Sargassum muticum (Phaeophyceae) on the Irish west coast. Estuar Coast Shelf Sci 90:185-194

Baiser B, Olden JD, Record S, Lockwood JL, McKinney ML (2012) Pattern and process of biotic homogenization in the New Pangaea. Proceedings Biol Sci 279:4772-7

460 Benedetti-Cecchi L, Bertocci I, Vaselli S, Maggi E (2006) Temporal variance reverses the 461 impact of high mean intensity of stress in climate change. Ecology 87:2489-2499

462 Bird NL, Chen LCM, McLachlan J (1979) Effects of temperature, light and salinity on growth 463 in culture of Chondrus crispus, Furcellaria lumbricalis, Gracilaria tikvahiae (Gigartinales, Rhodophyta), and Fucus serratus (Fucales, Phaeophyta). Bot Mar 22:521-528

465 Boyd P, Hutchins D (2012) Understanding the responses of ocean biota to a complex matrix 466 of cumulative anthropogenic change. Mar Ecol Prog Ser 470:125-135

467 Boyer KE, Kertesz JS, Bruno JF (2009) Biodiversity effects on productivity and stability of 468 marine macroalgal communities: the role of environmental context. Oikos 118:1062-1072

469 Britton-Simmons KH (2004) Direct and indirect effects of the introduced alga Sargassum 470 muticum on benthic, subtidal communities of Washington State, USA. Mar Ecol Ser 277:61$471 \quad 78$

472 Britton-Simmons KH (2006) Functional group diversity, resource preemption and the genesis 473 of invasion resistance in a community of marine algae. Oikos 3:395-401 
474 Bracken MES, Friberg SE, Gonzalez-Dorantes CA, Williams SL (2008) Functional 475 consequences of realistic biodiversity changes in a marine ecosystem. Proc Natl Acad Sci U S 476 A $105: 924-8$

477 Bustamante R, Branch G (1996) Large scale patterns and trophic structure of southern African 478 rocky shores: the roles of geographic variation and wave exposure. J Biogeogr 23:339479 351Campbell V, Murphy G, Romanuk TN (2011) Experimental design and the outcome and 480 interpretation of diversity-stability relations. Oikos 120:399-408

481 Carpentier C, Dahlhaus A, Giesen N van de, Maršálek B (2013) The influence of hard 482 substratum reflection and calibration profiles on in situ fluorescence measurements of benthic 483 microalgal biomass. Environ Sci Process Impacts 15:783-93

484 Clarke K, Gorley R (2006) PRIMER v6: User Maunal/Tutorial. PRIMER-E Ltd, Plymouth

485 Clarke K, Warwick R (2001) Changes in marine communities: an approach to statistical 486 analysis and interpretation, 2nd edn. PRIMER-E Ltd, Plymouth

487 Cottingham KL, Brown BL, Lennon JTJT (2001) Biodiversity may regulate the temporal 488 variability of ecological systems. Ecol Lett 4:72-85

489 Crain CM, Kroeker K, Halpern BS (2008) Interactive and cumulative effects of multiple human 490 stressors in marine systems. Ecol Lett 11:1304-1315

491 Crowe T, Frost N, Hawkins S (2011) Interactive effects of losing key grazers and ecosystem 492 engineers vary with environmental context. Mar Ecol Prog Ser 430:223-234

493 Crowe TP, Bracken MES, O’Connor NE (2012) Reality check: issues of scale and abstraction 494 in biodiversity research, and potential solutions. In: Paterson DM, Aspen RJ, Solan M (eds) 495 Marine Biodiversity and Ecosystem Functioning: Frameworks, Methodologies and Integration. 496 Oxford, p 185

497 Darling ES, Côté IM (2008) Quantifying the evidence for ecological synergies. Ecol Lett $498 \quad 11: 1278-86$

499 Davis MA, Grime JP, Thompson K, Davis A, Philip J (2000) Fluctuating resources in plant 500 communities : a general of invasibility theory. J Ecol 88:528-534 
Delgado O, Lapointe BE (1994) Nutrient-limited productivity of calcareous versus fleshy macroalgae in a eutrophic, carbonate-rich tropical marine environment. Coral Reefs 13:151159

504 Dixon PS, Irwine L. (Eds) (1977) Seaweeds of the British Isles, Volume 1 Part 1: Rhododphyta. Introduction, Nemaliales, Gigartinales. British Museum (Natural History), London

506 Donohue I, Petchey OL, Montoya JM, Jackson AL, McNally L, Viana M, Healy K, Lurgi M, 507 O'Connor NE, Emmerson MC (2013) On the dimensionality of ecological stability. Ecol Lett 508 $16: 421-9$

509 Donohue I, Hillebrand H, Montoya JM, Petchey OL, Pimm SL, Fowler MS, Healy K, Jackson

510 AL, Lurgi M, McClean D, O’Connor NE, O’Gorman EJ, Yang Q (2016) Navigating the complexity of ecological stability (F Adler, Ed.). Ecol Lett 19:1172-1185

512 Elmqvist T, Folke C, Nystrom M, Peterson G, Bengtsson J, Walker B, Norberg J (2003)

513 Response diversity, ecosystem change, and resilience. Front Ecol Environ 1:488-494

514 Firth LB, Crowe TP (2010) Competition and habitat suitability: small-scale segregation 515 underpins large-scale coexistence of key species on temperate rocky shores. Oecologia $516 \quad 162: 163-174$

517 Folke C, Carpenter S, Walker B, Scheffer M, Elmqvist T, Gunderson L, Holling CS (2004)

518 Regime shifts, resilience, and biodiversity in ecosystem management. Annu Rev Ecol Evol 519 Syst 35:557-581

520 Folt CL, Chen CY, Moore M V, Burnaford J (1999) Synergism and antagonism among multiple 521 stressors. Limnol Oceanogr 44:864-877

522 Gordillo FJL, Dring MJ, Savidge G (2002) Nitrate and phosphate uptake characteristics of 523 three species of brown algae cultured at low salinity. Mar Ecol Prog Ser 234:111-118

524 Gribben PE, Byers JE, Wright JT, Glasby TM (2013) Positive versus negative effects of an 525 invasive ecosystem engineer on different components of a marine ecosystem. Oikos 122:816526 824

Griffin J, Noël L, Crowe T, Burrows M, Hawkins S, Thompson R, Jenkins S (2010) Consumer effects on ecosystem functioning in rock pools: roles of species richness and composition. Mar Ecol Prog Ser 420:45-56 
530 Hawkins SJ, Proud SV, Spence SK, Southward AJ (1994) From the individual to the 531 community and beyond: water quality, stress indicators and key species in coastal waters. In:

532 Sutcliffe DW (ed) Water quality \& stress indicators in marine and freshwater systems: linking 533 levels of organisation. Freshwater Biological Association, Ambleside, UK, p 35-62

534 Hiscock S (1986) A Field Guide to the British Red Seaweeds. Field Studies Council

535 Hurlbert S (1984) Pseudoreplication and the Design of Ecological Field Experiments. Ecol 536 Monogr 54:187-211

537 Huston MA (1997) Hidden treatments in ecological experiments: re-evaluating the ecosystem 538 function of biodiversity. Oecologia 110:449-460

539 Ives AR, Carpenter SR (2007) Stability and diversity of ecosystems. Science 317:58-62

540 Jänes, H, Kotta, J, Pärnoja, M, Crowe, TP, Rindi, F, Orav-Kotta, H (2017) Functional traits of 541 marine macrophytes predict primary production. Funct Ecol 31, 975-986.

542 Kahlert M, McKie B (2014) Comparing new and conventional methods to estimate benthic 543 algal biomass and composition in freshwaters. Environ Sci Process impacts 16:2627-2634

544 Karez R, Engelbert S, Kraufvelin P, Pedersen MF, Sommer U (2004) Biomass response and 545 changes in composition of ephemeral macroalgal assemblages along an experimental gradient 546 of nutrient enrichment. Aquat Bot 78:103-117

547 Knight M, Parke M (1950) A Biological Study of Fucus Vesiculosus L. and F. Serratus L. J 548 Mar Biol Assoc United Kingdom 29:439

549 Lapointe BE, Barile PJ, Matzie WR (2004) Anthropogenic nutrient enrichment of seagrass and 550 coral reef communities in the Lower Florida Keys: discrimination of local versus regional 551 nitrogen sources. J Exp Mar Bio Ecol 308:24-58

552 Little C, Williams GA, Trowbridge CD (2009) The biology of rocky shores. Oxford University 553 Press

554 Loreau M, Naeem S, Inchausti P, Bengtsson J, Grime JP, Hector A, Hooper DU, Huston MA, 555 Raffaelli D, Schmid B, Tilman D, Wardle DA (2001) Biodiversity and ecosystem functioning: 556 current knowledge and future challenges. Science 294:804-8 
557 Lotze HK, Lenihan HS, Bourque BJ, Bradbury RH, Cooke RG, Kay MC, Kidwell SM, Kirby 558 MX, Peterson CH, Jackson JBC, Bay M (2006) Depletion, degradation, and recovery potential

559 of estuaries and coastal seas. Science 312:1806-1809

560 Lotze HK, Worm B (2002) Complex interactions of climatic and ecological controls on 561 macroalgal recruitment. Limnol Oceanogr 47:1734-1741

562 Masterson P, Arenas FA, Thompson RC, Jenkins SR (2008) Interaction of top down and 563 bottom up factors in intertidal rockpools: Effects on early successional macroalgal community composition, abundance and productivity. J Exp Mar Bio Ecol 363:12-20

McArdle BH, Anderson MJ (2001) Fitting multivariate models to community data: a comment on distance-based redundancy analysis. Ecology 82:290-297

567 Molinos JG, Donohue I (2010) Interactions among temporal patterns determine the effects of 568 multiple stressors. Ecol Appl 20:1794-1800

569 Mrowicki RJ, Maggs CA, Connor NEO (2014) Does wave exposure determine the interactive 570 effects of losing key grazers and ecosystem engineers? J Exp Mar Bio Ecol 461:416-424

571 Mrowicki RJ, Maggs CA, O’Connor NE (2015) Consistent effects of consumer species loss 572 across different habitats. Oikos 124:1555-1563

573 Mrowicki RJ, O’Connor NE, Donohue I (2016) Temporal variability of a single population can determine the vulnerability of communities to perturbations (C Thornber, Ed.). J Ecol 104:887575 897

576 Murphy RJ, Underwood AJ, Pinkerton MH, Range P (2005) Field spectrometry: New methods 577 to investigate epilithic micro-algae on rocky shores. J Exp Mar Bio Ecol 325:111-124

578 O'Connor NE (2013) Impacts of sewage outfalls on rocky shores : Incorporating scale, biotic assemblage structure and variability into monitoring tools. Ecol Indic 29:501-509

580 O'Connor NE, Bracken ME, Crowe TP, Donohue I (2015) Nutrient enrichment alters the 581 consequences of species loss. J Ecol 103:862-870

582 O'Connor NE, Crowe TP (2005) Biodiversity loss and ecosystem functioning : distinguishing 583 between number and identity of species. Ecology 86:1783-1796 
584 O'Connor NE, Crowe TP, McGrath D (2006) Effects of epibiotic algae on the survival, biomass 585 and recruitment of mussels, Mytilus L. (Bivalvia : Mollusca). J Exp Mar Bio Ecol 328:265$586 \quad 276$

587 Olden JD, Rooney TP (2006) On Defining and Quantifying Biotic Homogenization. Glob Ecol 588 Biogeogr 15:113-120

589 Paine RT, Tegner MJ, Johnson EA (1998) Compounded perturbations yield ecological 590 surprises. Ecosystems 1:535-545

591 Parker IM, Simberloff D, Lonsdale WM, Goodell K, Wonham M, Kareiva PM, Williamson 592 MH, Holle B Von, Moyle PB, Byers JE, Goldwasser L (1999) Impact: toward a framework for 593 understanding the ecological effects of invaders. Biol Invasions 1:3-19

594 Petersen JE, Hastings A (2001) Dimensional approaches to scaling experimental ecosystems: 595 designing mousetraps to catch elephants. Am Nat 157:324-33

596 Piazzi L, Ceccherelli G (2006) Persistence of biological invasion effects: Recovery of 597 macroalgal assemblages after removal of Caulerpa racemosa var. cylindracea. Estuar Coast 598 Shelf Sci 68:455-461

599 R Development Core Team (2011) R: a language and environment for statistical computing 600 (RDC Team, Ed.). R Found Stat Comput 1:409

601 Russell BD, Connell SD (2012) Origins and consequences of global and local stressors: 602 incorporating climatic and non-climatic phenomena that buffer or accelerate ecological change. 603 Mar Biol 159:2633-2639

604 Sanchez I, Fernandez C (2006) Resource availability and invasibility in an intertidal macroalgal 605 assemblage. Mar Ecol Ser 313:85-94

606 Sandulli R, Pinckney J (1999) Patch sizes and spatial patterns of meiobenthic copepods and 607 benthic microalgae in sandy sediments : a microscale approach. J Sea Res 41:179-187

608 Sharp J (1983) The distributions of inorganic nitrogen and dissolved and particulate organic 609 nitrogen in the sea. In: Elsevier (ed) Nitrogen in the marine environment.p 1-35 
610 Stachowicz JJ, Best RJ, Bracken MES, Graham MH (2008) Complementarity in marine

611 biodiversity manipulations: reconciling divergent evidence from field and mesocosm

612 experiments. Proc Natl Acad Sci U S A 105:18842-7

613 Strayer DL (2012) Eight questions about invasions and ecosystem functioning. Ecol Lett $614 \quad 15: 1199-1210$

615 Thomsen MS, Wernberg T, Olden JD, Griffin JN, Silliman BR (2011) A framework to study 616 the context-dependent impacts of marine invasions. J Exp Mar Bio Ecol 400:322-327

617 Thomsen MS, Wernberg T, South PM, Schiel DR (2016) To include or not to include (the 618 invader in community analyses)? That is the question. Biol Invasions 18:1515-1521

619 Thomsen MS, Wernberg T, Stæhr PA, Pedersen MF (2005) Spatio-temporal distribution 620 patterns of the invasive macroalga Sargassum muticum within a Danish Sargassum-bed. Helgol 621 Mar Res 60:50-58

622 Thresher RE, Kuris AM (2004) Options for managing invasive marine species. Biol Invasions $6236: 295-300$

624 Underwood AJ (2009) Components of design in ecological field experiments. Ann Zool Fenn $625 \quad 46: 93-111$

626 Uyà M, Maggi E, Mori G, Nuccio C, Gribben PE, Bulleri F (2017) Carry over effects of nutrient 627 addition on the recovery of an invasive seaweed from the winter die-back. Mar Environ Res

628 Vaz-Pinto F, Olabarria C, Arenas F (2013) Role of top-down and bottom-up forces on the 629 invasibility of intertidal macroalgal assemblages. J Sea Res 76:178-186

630 Vaz-Pinto F, Olabarria C, Arenas F (2014) Ecosystem functioning impacts of the invasive 631 seaweed Sargassum muticum (Fucales, Phaeophyceae). J Phycol 50:108-116

632 Vieira R, Pinto IS, Arenas F (2017) The role of nutrient enrichment in the invasion process in 633 intertidal rock pools. Hydrobiologia 797:183-198

634 Viejo RM (1997) The effects of colonization by Sargassum muticum on tidepool macroalgal 635 assemblages. J Mar Biol Assoc United Kingdom 77:325-340 
636 Vinebrooke RD, Cottingham KL, Norberg J, Scheffer M, Dodson SI, Maberly SC, Sommer U 637 (2004) Impacts of multiple stressors on biodiversity and ecosystem functioning: the role of 638 species co-tolerance. Oikos 104:451-457

639 Vitousek PM, D’Antonio CM, Loope L, Rejmanek M, Westbrooks R (1997) Introduced 640 species: a significant component of human-caused global environmental change. N Z J Ecol $641 \quad 21: 1-16$

642 Vye SR, Emmerson MC, Arenas F, Dick JTA, O’Connor NE (2015) Stressor intensity 643 determines antagonistic interactions between species invasion and multiple stressor effects on 644 ecosystem functioning. Oikos 124:1005-1012

645 Vye SR, Emmerson MC, Dick JTA, O’Connor NE (2017) Cumulative effects of multiple 646 stressors: An invasive oyster and nutrient enrichment reduce subsequent invasive barnacle 647 recruitment. J Exp Mar Bio Ecol 486:322-327

648 Warwick RM, Clarke KR (1993) Increased variability as a symptom of stress in marine 649 communities. J Exp Mar Bio Ecol 172:215-226

650 Wernberg T, Thomsen MS, Stæhr PA, Pedersen MF (2000) Comparative Phenology of 651 Sargassum muticum and Halidrys siliquosa (Phaeophyceae : Fucales) in Limfjorden, Denmark. 652 Bot Mar 43:31-39

653 White LF, Shurin JB (2011) Density dependent effects of an exotic marine macroalga on native 654 community diversity. J Exp Mar Bio Ecol 405:111-11

655 Williams G, Davies M, Nagarkar S (2000) Primary succession on a seasonal tropical rocky 656 shore: the relative roles of spatial heterogeneity and herbivory. Mar Ecol Prog Ser 203:81-94

657 Worm B, Reusch TBH, Lotze HK (2000) In situ nutrient enrichment: Methods for marine 658 benthic ecology. Int Rev Hydrobiol 85:359-375

659 Zavaleta ES, Hobbs RJ, Mooney HA (2001) Viewing invasive species removal in a whole660 ecosystem context. Trends Ecol Evol 16:454-459 
662 Table 1. ANOVA of effects of the presence of S. muticum and nutrient enrichment treatments

663 on the biomass of algae: a) total algal biomass (values in brackets represent algal biomass

664 with Sargassum muticum included); b) canopy algal biomass (values in brackets represent

665 algal biomass with Sargassum muticum included); c) sub-canopy algal biomass; d) turf algal

666 biomass; e) coralline algal biomass; f) green ephemeral biomass g) microalgal biomass.

667 Significant values are in bold $(P<0.05)$.

668

a) Total algal biomass

\begin{tabular}{|c|c|c|c|c|}
\hline Source & df & MS & $F$ & $P$ \\
\hline Invasion (=Inv.) & 2 & $2970(2198)$ & $4.491(3.504)$ & $0.019(0.042)$ \\
\hline Nutrient (=Nut.) & 2 & $50(103)$ & $0.075(0.165)$ & $0.928(0.849)$ \\
\hline Inv. x Nut. & 4 & $166(154)$ & $0.251(0.246)$ & $0.907(0.910)$ \\
\hline Residual & 32 & $661(627)$ & & \\
\hline \multicolumn{5}{|c|}{ b) Canopy algal biomass } \\
\hline Invasion (=Inv.) & 2 & $44.505(30.340)$ & $5.151(4.099)$ & $0.012(0.026)$ \\
\hline Nutrient (=Nut.) & 2 & $5.780(7.235)$ & $0.669(0.977)$ & $0.519(0.387)$ \\
\hline Inv. x Nut. & 4 & $10.918(11.560)$ & $1.264(1.562)$ & $0.305(0.208)$ \\
\hline Residual & 32 & $8.639(7.400)$ & & \\
\hline 679 & \multicolumn{4}{|c|}{ c) Sub-canopy algal biomass } \\
\hline Invasion (=Inv.) & 2 & 2.350 & 0.094 & 0.911 \\
\hline Nutrient (=Nut.) & 2 & 1.160 & 0.046 & 0.955 \\
\hline Inv. x Nut. & 4 & 78.740 & 3.154 & 0.027 \\
\hline Residual & 32 & 24.960 & & \\
\hline 684 & \multicolumn{4}{|c|}{ d) Turf algal biomass } \\
\hline Invasion (=Inv.) & 2 & 0.164 & 0.465 & 0.632 \\
\hline Nutrient (=Nut.) & 2 & 0.065 & 0.185 & 0.832 \\
\hline Inv. x Nut. & 4 & 0.106 & 0.302 & 0.874 \\
\hline Residual & 32 & 0.351 & & \\
\hline \multicolumn{5}{|c|}{ e) Coralline algal biomass } \\
\hline Invasion (=Inv.) & 2 & 2.127 & 2.875 & 0.071 \\
\hline Nutrient (=Nut.) & 2 & 1.872 & 2.530 & 0.095 \\
\hline
\end{tabular}




$\begin{array}{llcccc}692 & \text { Inv. x Nut. } & 4 & 19.688 & 1.663 & 0.183 \\ 693 & \text { Residual } & 32 & 0.740 & & \\ 694 & & \text { f) } & & \\ 695 & \text { Invasion (=Inv.) } & 2 & 7.333 & 4.369 & \mathbf{0 . 0 2 1} \\ 696 & \text { Nutrient (=Nut.) } & 2 & 1.725 & 1.028 & 0.369 \\ 697 & \text { Inv. x Nut. } & 4 & 4.526 & 2.696 & \mathbf{0 . 0 4 8} \\ 698 & \text { Residual } & 32 & 1.679 & & \\ 699 & & \text { g) Microalgal biomass } & & \\ 700 & \text { Invasion (=Inv.) } & 2 & 2.791 & 9.099 & \mathbf{0 . 0 0 1} \\ 701 & \text { Nutrient (=Nut.) } & 2 & 0.291 & 0.949 & 0.398 \\ 702 & \text { Inv. x Nut. } & 4 & 0.303 & 0.988 & 0.428 \\ 703 & \text { Residual } & 32 & 0.307 & & \end{array}$




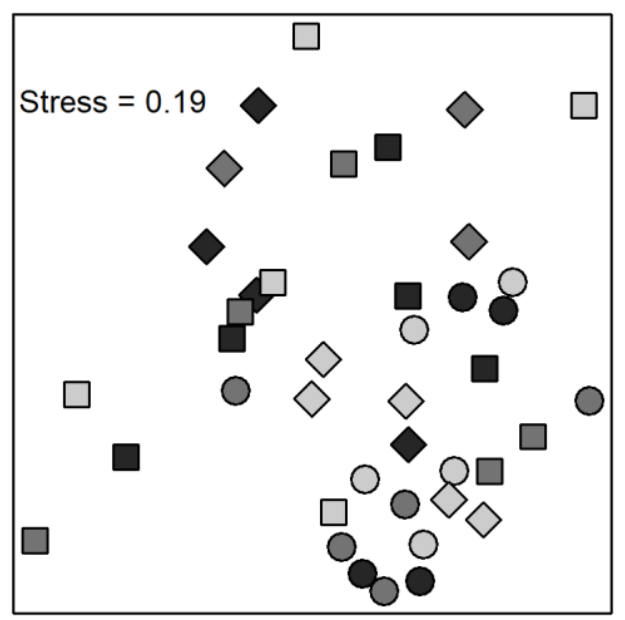

705

706 Figure 1. Non-metric multidimensional scaling plot (nMDS) of rock pool assemblages

707 (percentage cover of macroalgae and abundance of slow moving or sessile invertebrates

$708>1 \mathrm{~cm})$ in experimental treatments at the end of the experiment based on a Bray-Curtis

709 similarity matrix (data are square-root transformed). $\boldsymbol{Q}=$. muticum removed; $\mathbf{O}=S$.

710 muticum absent; $\mathbf{\square}=$ S. muticum present. Light grey symbols = ambient nutrient

711 concentrations, mid grey symbols = intermediate nutrient concentrations and dark grey

712 symbols $=$ high nutrient concentrations. 


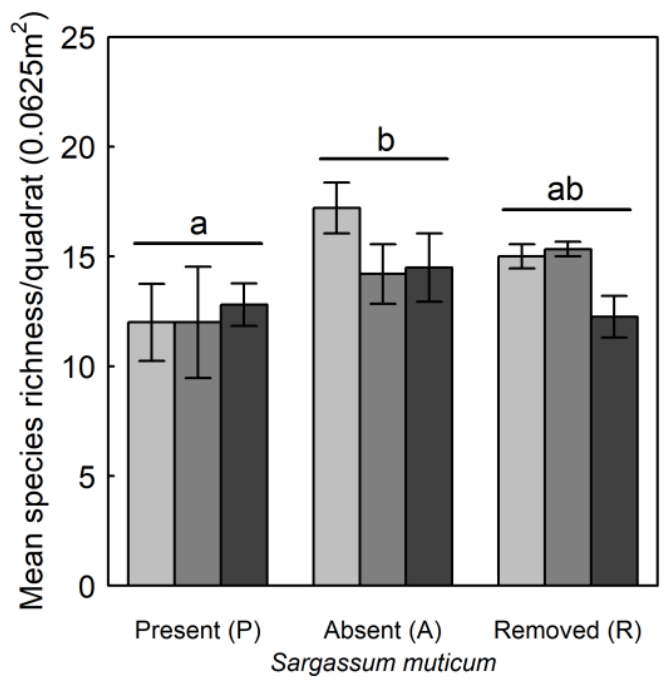

715 Figure 2. Mean species richness ( \pm S.E.) of rock pools in experimental treatments. Light grey

716 bars = ambient nutrient enrichment, mid grey bars = intermediate nutrient enrichment and

717 dark grey bars $=$ high nutrient enrichment $(n=3$ : invader removed, intermediate nutrient

718 enrichment; $n=4$ : invader removed, high nutrient enrichment and invader absent, high

719 nutrient enrichment; $n=5$ : all other treatments). Lower case letters indicate significant

720 differences among treatment levels or groups or groups of treatments $(P<0.05)$. 

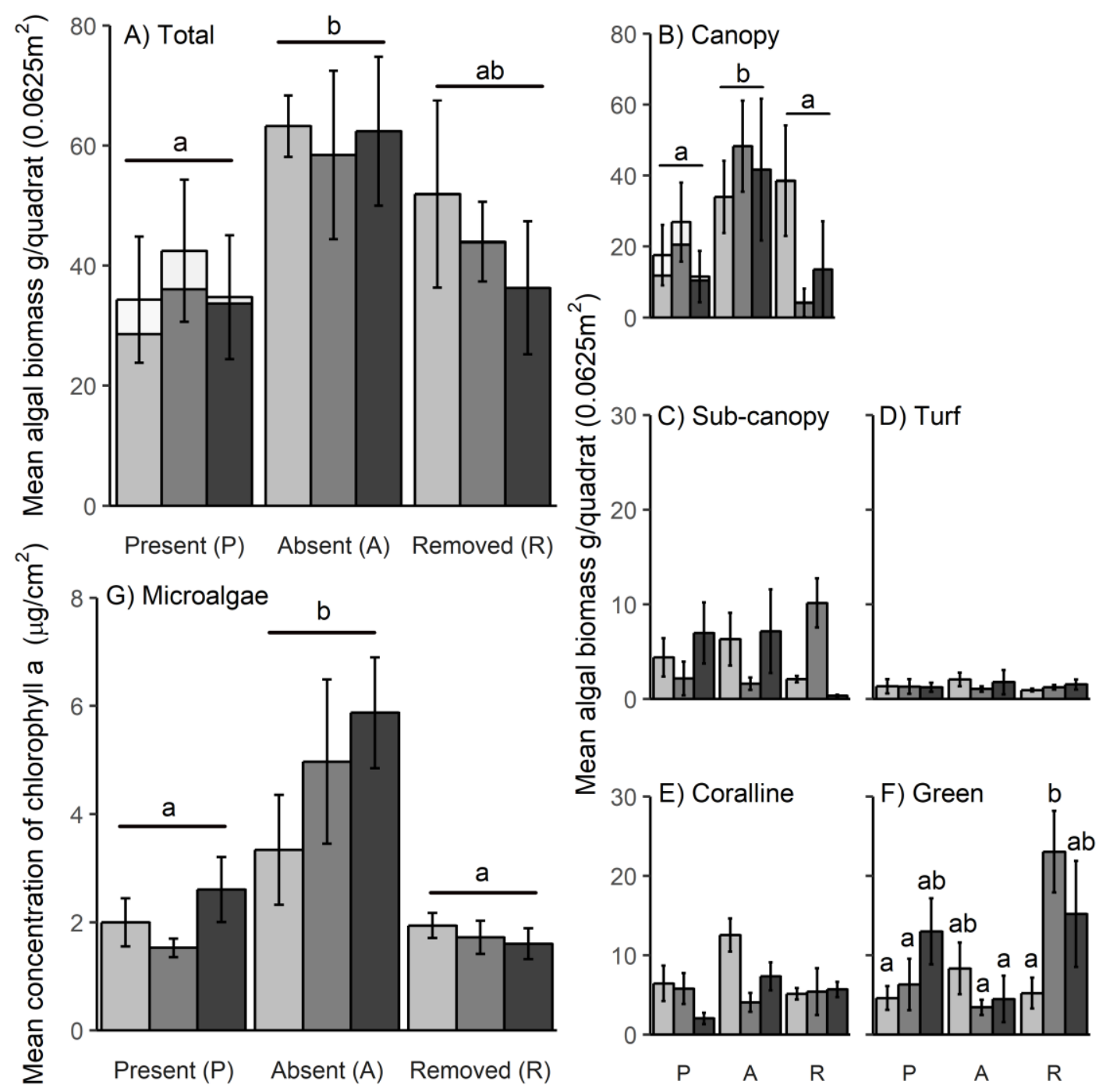

Sargassum muticum

724 Figure 3. Mean biomass ( \pm S.E.) of: A) total macroalgal biomass; B) canopy algal biomass;

725 C) sub-canopy algal biomass; D) turf algal biomass; E) coralline algal biomass, F) ephemeral 726 green algal biomass; and G) total microalgal chlorophyll $a$ concentration $( \pm$ S.E.), in rock

727 pools where S. muticum was present, absent or removed. Light bars = ambient nutrient

728 enrichment, mid grey bars = intermediate nutrient enrichment and dark grey bars = high

729 nutrient enrichment, open section of bars $=$ S. muticum biomass. Lower case letters indicate

730 significant differences among treatment levels or groups or groups of treatments $(P<0.05)$. 